\title{
A Descriptive Statistic Analysis Based on the Operation of Public Bicycle in Shenzhen
}

\author{
Yuxin Yang, Xinyi Zeng, Ling Lv, Yali Peng \\ Software College of Jiangxi Normal University \\ Nanchang, China
}

\begin{abstract}
Currently, traveling by bike has been widely accepted by the public. However, the public bicycle system is in need of an optimization scheme owing to its poor operating efficiency. In this paper, real operating data of Shenzhen city public bicycle system during July 2016 are used as the data bases, all of which were analyzed by EXCEL, SPSS and RStudio. After the analysis, the following operating rules are found: there are morning and evening peaks in bike borrowing and return; change of bike lending and return flow during same period or at same outlet type of valid date is slight; the public bike flow at varied outlet types differ in workdays and holiday; large number of users lend bike once a week in workdays, while some users lend bike three or more times a week. To improve the demand of public bicycle, frequent users should be delved deeper. The research results may provide a theoretical basis and ideas for the operation optimization of public bicycle system.
\end{abstract}

Keywords-Statistics; Public bicycle; Regression analysis; Running law

\section{INTRODUCTION}

At present, the problem of traffic congestion is becoming increasingly severe, [1] and environmental problems, like air quality and PM2.5, [2] are also affecting people's lives. Traveling by bike has the advantage of low-carbon, environmental, convenient and efficient. Therefore, it is more and more accepted by people. At the same time, local government departments established and improved the public bicycle system for encouraging people to travel by bike. [3]But in the usage of public bicycles, the citizens are often troubled by problems --- lack of bikes and piles.
In this thesis, data of borrowing and return of Shenzhen public bicycle will be analyzed by means of the descriptive statistic method. [4] This paper attempts to attain the basic law of the borrowing and return of bike, thereby providing a theoretical basis and ideas for the optimization of public bicycle system.

\section{THE SOURCES AND ORGANIZATION OF DATA}

From the real Shenzhen public bicycle operators did the data of this paper come. The data include the date and place of lending, and the stock and capacity of bicycles outlet. All outlets consist of four categories: residential area, common service area, and transportation hub and business center. In which, the common service area includes public services area, government agency and industrial park; commercial center include Business Center, leisure and entertainment complex. Therefore, the four categories can be divided into seven categories.

To understand the operation status of Shenzhen public bicycle system from a macro perspective, we must find the best indicator that can reflect the overall level. We leave the bicycle outlet type first, and add up the times of borrowing and return of bikes respectively. In workday and holiday, users' travel rule diverges greatly, so it' $s$ necessary to analyze them respectively. Here, we will analyze the data of workday in detail mainly, and the same analysis method will be applied to analyze holiday's data. The table 1 contains data of Shenzhen public bicycle in five consecutive working days. They will be used in analysis of the time distribution of public bicycle traffic in Shenzhen:

TABLE I USE TIME DISTRIBUTION OF PUBLIC BICYCLE IN SHENZHEN

\begin{tabular}{|c|c|c|c|c|c|c|c|c|c|c|c|c|}
\hline $\begin{array}{l}\text { Borrowing } \\
\text { situation }\end{array}$ & rent & return & rent & return & rent & return & rent & return & rent & return & rent & return \\
\hline $0: 00-1: 00$ & 26 & 34 & 20 & 27 & 21 & 31 & 25 & 32 & 23 & 34 & 115 & 158 \\
\hline $2: 00-3: 00$ & 2 & 3 & 1 & 2 & 2 & 3 & 4 & 2 & 4 & 6 & 13 & 16 \\
\hline $4: 00-5: 00$ & 4 & 1 & 8 & 4 & 8 & 3 & 3 & 5 & 8 & 4 & 31 & 17 \\
\hline $5: 00-6: 00$ & 40 & 18 & 43 & 16 & 32 & 16 & 54 & 19 & 49 & 19 & 218 & 88 \\
\hline $6: 00-7: 00$ & 202 & 127 & 150 & 106 & 122 & 71 & 170 & 120 & 179 & 121 & 823 & 545 \\
\hline $7: 00-8: 00$ & 461 & 409 & 469 & 368 & 327 & 270 & 491 & 395 & 462 & 406 & 2210 & 1848 \\
\hline
\end{tabular}




\begin{tabular}{|c|c|c|c|c|c|c|c|c|c|c|c|c|}
\hline \multicolumn{10}{|c|}{ TABLE 1, cont. } \\
\hline 8:00-9:00 & 521 & 560 & 547 & 601 & 475 & 484 & 505 & 565 & 525 & 531 & 2573 & 2741 \\
\hline 9:00-10:00 & 257 & 276 & 279 & 297 & 260 & 237 & 286 & 295 & 281 & 284 & 1363 & 1389 \\
\hline $10: 00-11: 00$ & 205 & 223 & 204 & 234 & 162 & 216 & 200 & 225 & 189 & 243 & 960 & 1141 \\
\hline 11:00-12:00 & 175 & 183 & 131 & 148 & 139 & 161 & 157 & 149 & 139 & 163 & 741 & 804 \\
\hline 12:00-13:00 & 154 & 153 & 136 & 140 & 94 & 99 & 134 & 148 & 150 & 145 & 668 & 685 \\
\hline 13:00-14:00 & 117 & 129 & 131 & 124 & 111 & 103 & 138 & 122 & 151 & 131 & 648 & 609 \\
\hline 14:00-15:00 & 149 & 141 & 170 & 156 & 175 & 154 & 191 & 195 & 178 & 185 & 863 & 831 \\
\hline 15:00-16:00 & 194 & 163 & 192 & 159 & 181 & 174 & 153 & 150 & 164 & 170 & 884 & 816 \\
\hline 16:00-17:00 & 279 & 221 & 238 & 228 & 226 & 191 & 225 & 212 & 208 & 150 & 1176 & 1002 \\
\hline 17:00-18:00 & 338 & 345 & 298 & 283 & 324 & 296 & 333 & 284 & 331 & 313 & 1624 & 1521 \\
\hline $18: 00-19: 00$ & 418 & 421 & 485 & 469 & 441 & 458 & 515 & 489 & 475 & 489 & 2334 & 2326 \\
\hline 19:00-20:00 & 388 & 411 & 339 & 385 & 327 & 362 & 356 & 404 & 337 & 366 & 1747 & 1928 \\
\hline 20:00-21:00 & 233 & 268 & 240 & 255 & 217 & 250 & 287 & 311 & 246 & 250 & 1223 & 1334 \\
\hline $21: 00-22: 00$ & 190 & 220 & 187 & 231 & 189 & 204 & 172 & 230 & 166 & 211 & 904 & 1096 \\
\hline $22: 00-23: 00$ & 140 & 170 & 113 & 138 & 105 & 143 & 122 & 143 & 150 & 167 & 630 & 761 \\
\hline $23: 00-24: 00$ & 40 & 53 & 60 & 80 & 41 & 53 & 42 & 50 & 42 & 73 & 225 & 309 \\
\hline Total & 4543 & 4540 & 4453 & 4464 & 3989 & 3991 & 4565 & 4552 & 4466 & 4475 & 22016 & 22022 \\
\hline
\end{tabular}

In order to understand the space distribution of public bicycle flow in Shenzhen further, we need to analyze the flow direction of the data. We analyze the basic flow through the statistics of public bike outlet types. The table 2 below is the borrowing and return data of Shenzhen public bicycle in five consecutive workdays, which will be used to analyze the space distribution of public bicycle traffic in Shenzhen city:

TABLE II SPACE DISTRIBUTION OF PUBLIC BICYCLE IN SHENZHEN

\begin{tabular}{|c|c|c|c|c|c|c|c|c|c|c|c|c|}
\hline Date & \multicolumn{2}{|c|}{$\mathbf{2 0 1 6 - 7 - 4}$} & \multicolumn{2}{|c|}{$\mathbf{2 0 1 6 - 7 - 5}$} & \multicolumn{2}{|c|}{$\mathbf{2 0 1 6 - 7 - 6}$} & \multicolumn{2}{|c|}{ 2016-7-7 } & \multicolumn{2}{|c|}{$\mathbf{2 0 1 6 - 7 - 8}$} & \multicolumn{2}{|c|}{ Total } \\
\hline Borrowing situation & rent & borrow & rent & borrow & rent & borrow & rent & borrow & rent & borrow & rent & borrow \\
\hline industrial park & 543 & 581 & 555 & 561 & 561 & 536 & 544 & 496 & 533 & 535 & 2736 & 2709 \\
\hline public service & 633 & 596 & 639 & 592 & 459 & 489 & 629 & 589 & 588 & 646 & 2948 & 2912 \\
\hline Traffic hub & 835 & 808 & 807 & 840 & 730 & 769 & 809 & 843 & 834 & 831 & 4015 & 4091 \\
\hline Commercial Centre & 353 & 336 & 359 & 350 & 273 & 281 & 374 & 378 & 337 & 331 & 1696 & 1676 \\
\hline Living quarters & 1001 & 1101 & 946 & 925 & 867 & 867 & 1053 & 1104 & 1046 & 982 & 4913 & 4979 \\
\hline $\begin{array}{c}\text { Recreation \& } \\
\text { Entertainment }\end{array}$ & 167 & 152 & 156 & 161 & 169 & 145 & 162 & 174 & 181 & 167 & 835 & 799 \\
\hline Government office & 863 & 839 & 834 & 870 & 803 & 782 & 821 & 796 & 794 & 828 & 4115 & 4115 \\
\hline Unknown & 148 & 127 & 157 & 165 & 127 & 122 & 173 & 172 & 153 & 155 & 758 & 741 \\
\hline total & 4543 & 4540 & 4453 & 4464 & 3989 & 3991 & 4565 & 4552 & 4466 & 4475 & 22016 & 22022 \\
\hline
\end{tabular}

\section{ANALYSIS OF SHENZHEN PUBLIC BICYCLE FLOW}

From the data sheet above, we can know the conditions of Shenzhen public bicycle system in different periods at outlet of varied types. To achieve the goal of analyzing and understanding the change of bicycle traffic at outlet of varied types during different period, we will organize the data with
EXCEL, SPSS and RStudio, and then use descriptive analysis and regression analysis [5-6] to analyze the bicycle traffic distribution rules of Shenzhen city public bicycle system. Also, we will analyze and describe operation feature of Shenzhen bicycle system from the view of travel time of user and types 
of outlet. These spatial analysis methods are the most basic and commonly used statistical analysis methods.

\section{A. Descriptive analysis on the distribution law of the total flow of bicycles}

The data in table 1 show that the borrowing data are basically balance in varied period of different workdays, which can reflect the time distribution feature of public bicycle system under current circumstances. To show the characteristics more intuitively, we make two line charts, using the lending and return data of workdays in July, as shown in figure 1 and figure 2 respectively:

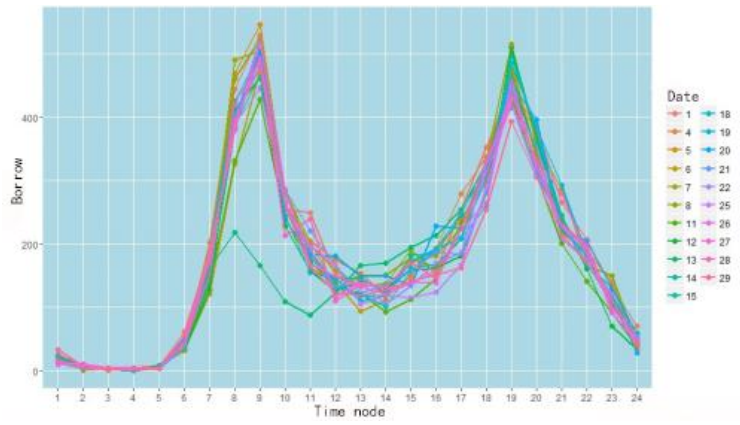

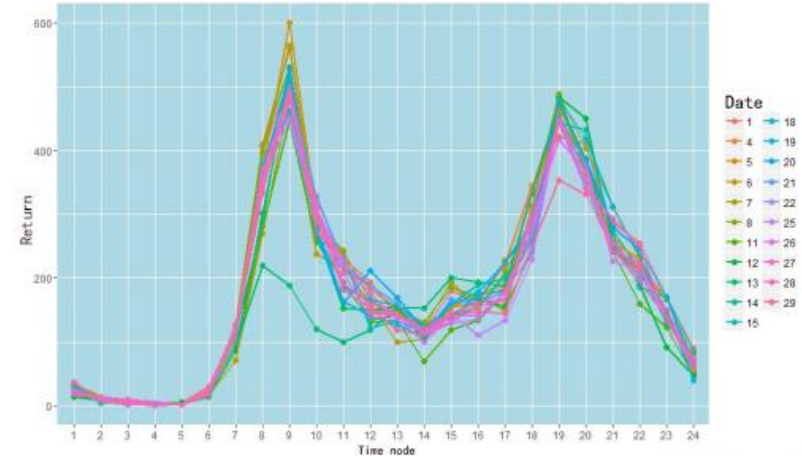

Fig. 2. Statistics of the number of bikes return in July

From the above line chart, we can clearly see that the borrowing and return trend of public bicycle in workdays of July is basically the same. There is a peak around 9:00, and another peak around 19:00.

In the meantime, using the data in table 1 , we can calculate the average value, standard deviation and coefficient of variation of bike lending and return in Shenzhen city as follow table 3:

Fig. 1. Statistics of the number of bikes lending in July

TABLE III PARAMETERS OF BIKE LENDING FLOW IN EACH PERIOD OF SHENZHEN BICYCLE SYSTEM

\begin{tabular}{|c|c|c|c|c|c|c|c|c|c|c|c|c|c|}
\hline Date & $\begin{array}{c}0: 00 \\
- \\
1: 00\end{array}$ & $\begin{array}{c}1: 00- \\
2: 00\end{array}$ & $\begin{array}{c}2: 00- \\
3: 00\end{array}$ & $\begin{array}{c}3: 00- \\
4: 00\end{array}$ & $\begin{array}{c}4: 00- \\
5: 00\end{array}$ & $\begin{array}{c}5: 00- \\
6: 00\end{array}$ & $\begin{array}{c}6: 00- \\
7: 00\end{array}$ & $\begin{array}{c}\text { 7:00- } \\
\text { 8:00 }\end{array}$ & $\begin{array}{c}\text { 8:00- } \\
9: 00\end{array}$ & $\begin{array}{l}\text { 9:00- } \\
10: 00\end{array}$ & $\begin{array}{c}10: 00 \\
- \\
11: 00\end{array}$ & $\begin{array}{c}11: 00 \\
- \\
12: 00\end{array}$ & TOTAL \\
\hline $\begin{array}{l}\text { mean } \\
\text { value }\end{array}$ & 23 & 6.2 & 2.6 & 2.4 & 6.2 & 43.6 & 164.6 & 442 & 514.6 & 272.6 & 192 & 148.2 & \\
\hline $\begin{array}{l}\text { standard } \\
\text { deviation }\end{array}$ & 2.550 & 2.950 & 1.342 & 1.517 & 2.490 & 8.444 & 30.262 & 65.414 & 26.736 & 13.164 & 17.930 & 17.754 & \\
\hline $\begin{array}{l}\text { Variation } \\
\text { coefficient }\end{array}$ & 0.111 & 0.476 & 0.516 & 0.632 & 0.402 & 0.194 & 0.184 & 0.148 & 0.052 & 0.048 & 0.093 & 0.120 & \\
\hline Date & $\begin{array}{c}12: 00 \\
- \\
13: 00\end{array}$ & $\begin{array}{c}13: 00 \\
- \\
14: 00\end{array}$ & $\begin{array}{c}14: 00 \\
\frac{-}{15: 00}\end{array}$ & $\begin{array}{c}15: 00 \\
\frac{-}{16: 00}\end{array}$ & $\begin{array}{c}16: 00 \\
\frac{17: 00}{}\end{array}$ & $\begin{array}{c}17: 00 \\
- \\
18: 00\end{array}$ & $\begin{array}{c}18: 00 \\
- \\
19: 00\end{array}$ & $\begin{array}{c}19: 00 \\
- \\
20: 00\end{array}$ & $\begin{array}{c}20: 00 \\
- \\
21: 00\end{array}$ & $\begin{array}{c}21: 00 \\
- \\
22: 00\end{array}$ & $\begin{array}{c}22: 00 \\
- \\
23: 00\end{array}$ & $\begin{array}{c}23: 00 \\
- \\
24: 00\end{array}$ & \\
\hline $\begin{array}{l}\text { mean } \\
\text { value }\end{array}$ & 133.6 & 129.6 & 172.6 & 176.8 & 235.2 & 324.8 & 466.8 & 349.4 & 244.6 & 180.8 & 126 & 45 & 4403.2 \\
\hline $\begin{array}{c}\text { standard } \\
\text { deviation }\end{array}$ & 23.766 & 16.087 & 15.307 & 17.852 & 26.715 & 15.802 & 37.976 & 23.965 & 26.063 & 11.032 & 18.695 & 8.426 & 236.489 \\
\hline $\begin{array}{l}\text { Variation } \\
\text { coefficient }\end{array}$ & 0.178 & 0.124 & 0.089 & 0.101 & 0.114 & 0.049 & 0.081 & 0.069 & 0.107 & 0.061 & 0.148 & 0.187 & 0.054 \\
\hline
\end{tabular}

On the one hand, according to the average value, we can know that the total amount of bicycle lending is about 4403 times a day, and during 8:00 - 9:00, the bicycle lending was significantly more frequent than other periods. On the other hand, we can come to the conclusion that the coefficient of variation in different period of a day is 0.054 , which means that the change of bike lending in varied period is slight. Also, we find that the traffic flow parameters own the same feature. Thus, we can draw the conclusion that user's bike time and behavior habits are daily cycled, and the total amount of each hour is basically fixed [7]. 
B. Analysis on flow direction between bicycle outlets

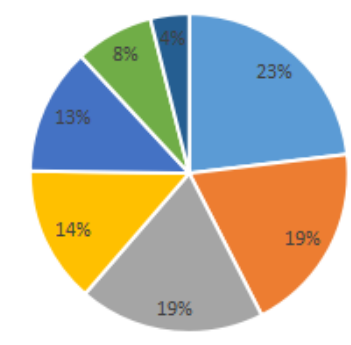

We make the following pie chart, as is shown in figure 3, so as to understand users' flow between outlets of different types more intuitively.

From the above chart, we can easily know that the proportion of lending from residential area is the largest, while the proportion of lending from other sites are relatively small. This phenomenon can provide us with the site planning basis for the initial layout of the bike outlets.

Besides, using the data of table 2, we can attain the mean value, standard deviation and coefficient of variation of bike lending and return in varied outlets as follows table 4 and table 5:

Fig. 3. The statistics of the bike lending outlets

TABLE IV BICYCLE LENDING FLOW PARAMETERS OF SHENZHEN PUBLIC BICYCLE SYSTEM

\begin{tabular}{|c|c|c|c|c|c|c|c|c|c|}
\hline Dot type & $\begin{array}{c}\text { industrial } \\
\text { park }\end{array}$ & $\begin{array}{c}\text { public } \\
\text { service }\end{array}$ & $\begin{array}{c}\text { Traffic } \\
\text { hub }\end{array}$ & $\begin{array}{c}\text { Commercial } \\
\text { Centre }\end{array}$ & $\begin{array}{c}\text { Living } \\
\text { quarters }\end{array}$ & $\begin{array}{c}\text { Recreation \& } \\
\text { Entertainment }\end{array}$ & $\begin{array}{c}\text { Government } \\
\text { office }\end{array}$ & Unknown & total \\
\hline $\begin{array}{l}\text { mean } \\
\text { value }\end{array}$ & 547.2 & 589.6 & 803 & 339.2 & 982.6 & 167 & 823 & 151.6 & 4403.2 \\
\hline $\begin{array}{c}\text { standard } \\
\text { deviation }\end{array}$ & 10.964 & 75.722 & 42.913 & 39.309 & 77.487 & 9.301 & 27.230 & 16.637 & 236.489 \\
\hline $\begin{array}{l}\text { Variation } \\
\text { coefficient }\end{array}$ & 0.020 & 0.128 & 0.053 & 0.116 & 0.079 & 0.056 & 0.033 & 0.110 & 0.054 \\
\hline
\end{tabular}

TABLE V FLOW PARAMETERS OF SHENZHEN PUBLIC BICYCLE SYSTEM

\begin{tabular}{|c|c|c|c|c|c|c|c|c|}
\hline Dot type & $\begin{array}{c}\text { industrial } \\
\text { park }\end{array}$ & $\begin{array}{c}\text { public } \\
\text { service }\end{array}$ & $\begin{array}{c}\text { Traffic } \\
\text { hub }\end{array}$ & $\begin{array}{c}\text { Commercial } \\
\text { Centre }\end{array}$ & $\begin{array}{c}\text { Living } \\
\text { quarters }\end{array}$ & $\begin{array}{c}\text { Recreation \& } \\
\text { Entertainment }\end{array}$ & $\begin{array}{c}\text { Government } \\
\text { office }\end{array}$ & $\begin{array}{c}\text { Unknown } \\
\text { total } \\
\text { mean } \\
\text { value }\end{array}$ \\
541.8 & 582.4 & 818.2 & 335.2 & 995.8 & 159.8 & 823 \\
\hline $\begin{array}{c}\text { standard } \\
\text { deviation }\end{array}$ & 31.948 & 57.204 & 30.736 & 35.379 & 105.554 & 11.563 & 3404.4 \\
\hline $\begin{array}{c}\text { Variation } \\
\text { coefficient }\end{array}$ & 0.059 & 0.098 & 0.038 & 0.106 & 0.106 & 0.072 & 22.532 & 234.312 \\
\hline
\end{tabular}

On the one hand, according to the average value, we can see that the total lending amount is about 4403 times per day, and the returning amount is about 4404 bikes per day, besides, the lending and return amount in residential area outlets are the highest. On the other hand, the variation coefficient of lending and return of bicycle is around 0.1 --- the minimum value is 0.02 , and the maximum value is 0.152 --- which means the lending and return amount at various outlets all day is basically the same every day.

In order to analyze the user flow between different outlets in detail, we make a pie chart based on the data of user flow between outlets of varied types in five consecutive days of the first week of July 2016. The pie chart is as follows figure 4:

Obviously, the largest flow emerges between government agencies in working days, it' $\mathrm{s}$ about $10.99 \%$, followed by residential area - residential area (about 8.29\%), transportation hub - transportation hub (about 5.62\%), industrial park industrial park (about 5.11\%) and traffic hub - residential area (about $5.01 \%$ ), while the flow amount between other outlets are relatively small.

Similarly, the distribution feature of flow between different outlets in holidays can be attained, basing on the data of all holidays in July. The characteristic is different from that of workdays: during holidays, the largest flow appears in residential area - residential area, which accounts for $10.25 \%$. Followed by government agency - government agency (about $8.64 \%$ ), transportation hub - transportation hub (about 6.64\%), industrial park - industrial park (about 6.40\%). The flow amount of users between other outlets are relatively small.

Other traffic between users is relatively small.
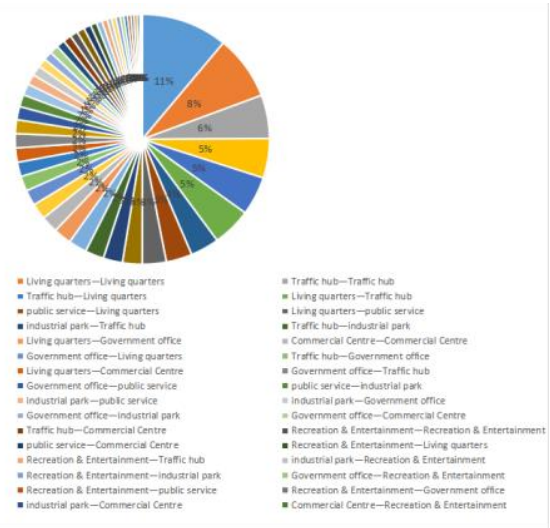

Fig. 4. Flow distribution of public bicycles among varied types of outlet in Shenzhen 


\section{The characteristics of public bicycle users in Shenzhen}

In order to improve the operating efficiency of public bicycles, we not only need to understand the current operation situation of public bicycle, but also need to further identify the user characteristics and mine potential benefits [8]
We know appeared 15531 users by statistical data of four weeks consecutive working days in July. We analyze by the frequency of the use of bicycles, classify the data around the statistics of the 5 days a week, the number of days the user, the following table 6 :

TABLE VI NUMBER OF DAYS PER WEEK FOR USERS

\begin{tabular}{|c|c|c|c|c|c|c|c|c|}
\hline Number of days & $\mathbf{0}$ & $\mathbf{1}$ & $\mathbf{2}$ & $\mathbf{3}$ & $\mathbf{4}$ & $\mathbf{5}$ & $\begin{array}{c}\text { 5 days of user } \\
\text { accounts }\end{array}$ & $\begin{array}{c}\text { 3 days and more than } \\
\mathbf{3} \text { days the proportion } \\
\text { of users }\end{array}$ \\
\hline First week & 1726 & 6686 & 866 & 686 & 495 & 376 & 0.035 & 0.144 \\
\hline Second weeks & 1803 & 6881 & 826 & 607 & 457 & 261 & 0.024 & 0.122 \\
\hline Third weeks & 1685 & 6826 & 892 & 568 & 499 & 365 & 0.034 & 0.132 \\
\hline Fourth week & 3242 & 3992 & 1942 & 847 & 495 & 317 & 0.029 & 0.153 \\
\hline
\end{tabular}

From the table, we can find a large number of users use once a week, we regard as the law of users who' s frequency of use is greater than or equal to 3 for a week, and about $3 \%$ of users within a week every day, and 3 days and more users

accounted for more than $12 \%$, the difference between our two that is the mining of user benefits.

For further statistical analysis of the above data, the following table 7 :

TABLE VII THE NUMBER OF WEEKS MORE THAN 3 DAYS PER WEEK

\begin{tabular}{|c|c|c|c|c|c|}
\hline $\begin{array}{c}\text { The number of } \\
\text { weeks }\end{array}$ & $\mathbf{0}$ & $\mathbf{1}$ & $\mathbf{2}$ & $\mathbf{3}$ & $\mathbf{4}$ \\
\hline user & 7840 & 1428 & 616 & 491 & 460 \\
\hline User proportion & 0.724 & 0.132 & 0.057 & 0.045 & 0.042 \\
\hline
\end{tabular}

Obviously, the number of users per week accounted for $4.2 \%$, but there are still a large number of regular users within four weeks of 2 - 3 weeks appear more than 3 days, obviously, there are a lot of potential user benefits.

\section{CONCLUSION}

In this paper, based on basic data of a month in Shenzhen city public bicycle system, we make the descriptive analysis by EXCEL, SPSS and Studio software. Taking July 2016 data as an example to illustrate the flow law of Shenzhen city public bicycle, and then borrow the car dot type analysis, get the characteristics of user travel.

First, we found the bike running all day long appeared the first peaking the 8::00 - 9:00 morning, evening peak appeared in 18:00 19:00; secondly, each time by bike fluctuation are smaller; from the living area to lend the largest amount of work on the government to the government departments, the largest flow of holidays in the living quarters living area to the user among the largest flow; and various outlets daily fluctuations, showed a steady state; finally, we analyze the frequency for the user, found that 5 consecutive working days about $13.78 \%$ users appear not less than 3 days, there are about $4.2 \%$ users each week for four consecutive weeks of not less than 3 days; at the same time, we found the statistics a large number of potential users. According to the different classification rules can also be excavated to different potential users, such as: according to the user often appear network information classification. I believe that through continuous data mining, bicycle system will achieve the best operating efficiency.

\section{ACKNOWLEDGEMENT}

The corresponding author of this paper is Yali Peng. This work was supported by National Natural Science Foundation of China No. 71661015, The Major Soft Science Research Program of Jiangxi Province No. 20161BBA10015.

\section{REFERENCES}

[1] Yu Sheng, Sheng'ao Yang, Wenling Tang, Xiukun Yang. Analysis of urban traffic congestion and scientific management [J]. Green technology, 2016, (22):123-124.

[2] Mei Zheng,Yanjun Zhang,Caiqing Yan,Xianlei Zhu ,James J.Schauer,Yuanhang Zhang. A survey of PM2.5 source apportionment methods in China [J]. Journal of Peking University (Natural Science Edition), 2014, (06):1141-1154.

[3] Tianjun Feng. Analysis of the effect of public bicycle transportation system [D].Jilin University, 2016.

[4] Hongmeng Song, Tiantian Ma, Jianxun Jiang. Descriptive statistics analysis of South Zhongguancun streetcar based on traffic. [J]. Journal of Minzu University of China (Natural Science Edition), 2013 (S1):140-144.

[5] Runxing Liu. Principal component regression analysis using SPSS [J] Chinese public health, 2001, (08):74-76.

[6] Shixin Ruan. The implementation, improvement and application of some regression analysis methods [D].Jilin University, 2005.

[7] Peng Yali, Lv Ling, Xie Zhongfu, Zhang Zhiming, Xu Hong. Research on Layered-Partition Communication Model on Intelligent Urban VANET [J] Journal of Jiangxi Normal University, 2016, 6 (40): 627-634.

[8] Lu Bai. Potential Group Mining Based on user annotation behavior and interest points $[\mathrm{J}]$. Technology entrepreneurship monthly, 2015, (22):103-10. 